\title{
ANALISIS DISIPLIN DAN KUASA TUBUH MICHEL FOUCAULT \\ DALAM KEHIDUPAN SANTRI PONDOK KEBON JAMBU AL-ISLAMY PESANTREN BABAKAN CIWARINGIN CIREBON
}

\author{
Misbah Mustofa \\ Mahasiswa IAIN Syekh Nurjati Cirebon
}

\begin{abstract}
Abstrak: Salah satu pemikiran Michel Foucault yang menarik adalah konsepnya tentang kuasa, karena kuasa yang dibawa olehnya berbeda dengan konsep kuasa yang dibawa oleh para pemikir lainnya. Salah satu pembahasan mengenai kuasa dari Michel Foucalt ini ialah konsep disiplin tubuh. Disiplin Tubuh merupakan suatu usaha dalam menguasai tubuh subjek untuk kemudian didisiplinkan agar menjadi individu yang berguna melalui berbagai praktek tanpa disadari oleh subjek tersebut. Praktek relasi kuasa dalam disiplin tubuh tersebut dapat dilihat pada beberapa tempat, aktifitas dan instansi, salah satuya ialah Pesantren. Kajian dalam tulisan ini mencoba untuk menggambarkan bagaimana terjadinya proses relasi kuasa terkait dengan pendisiplinan tubuh yang ada dalam kehidupan Pondok Kebon Jambu Al-Islamy Pesantren Babakan Ciwaringin dengan menggunakan konsep disiplin tubuh dari Michel Foucault. Praktek pendisiplinan tubuh yang ada di Pondok Kebon Jambu Pesantren Babakan Ciwaringin Cirebon terbentuk melalui beberapa konsep yang saling terbagi dan saling menguatkan, diantaranya adalah: Pengawasan secara hierarkis, normalisasi, dan terakhir adalah ujian.
\end{abstract}

Kata kunci: Michel Foucault, pondok pesantren, kuasa, disiplin tubuh.

\section{A. Pendahuluan}

Kuasa kerap kali dibicarakan oleh para filsuf kontemporer, salah satu filsuf yang sering kali membicarakan tentang kuasa yaitu Michel Foucault. Dia merupakan salah seorang teoritisi kontemporer. Kuasa yang dibawakan oleh Foucault berbeda dengan teoritisi lainnya. Jika teoritisi lain mengatakan kuasa dalam ruang lingkup makro, Foucault justru sebaliknya, Dia mengatakan kuasa dalam ruang lingkup mikro. Menurut Foucault, kuasa harus dipandang sebagai relasi-relasi yang beragam dan 
tersebar seperti jaringan, yang mempunyai ruang lingkup strategis. ${ }^{1}$ Dalam pandangannya, kuasa tidaklah dimiliki tetapi dipraktekan. Kuasa bukanlah milik, melainkan strategi. Strategi kuasa berlangsung dimana-mana karena dimana saja terdapat susunan, aturan-aturan, sistem-sistem regulasi, dimana ada manusia yang berhubungan satu sama lain, disitu kuasa sedang bekerja. Ia juga mengungkapkan bahwa kuasa tidak bersifat deskruktif melainkan produktif, maka dari itu kuasa juga bersifat positif.

Salah satu pembahasan tentang kuasa dari Foucalt ialah konsepnya mengenai kuasa terhadap tubuh, konsep ini dinamakan dengan "disiplin tubuh". Disiplin tubuh merupakan usaha untuk mengawasi seluruh aspek yang ada dalam tubuh individu meliputi: tingkah laku, kecerdasan, bagaimana berpenampilan, hingga bagaimana ia menjadi individu yang lebih berguna. Disiplin tubuh adalah tekhnologi kuasa yang dijalankan untuk mendisiplinkan tubuh dan membuatnya menjadi tubuh yang patuh dan berguna. ${ }^{2}$ Foucault menyebutnya sebagai anatomi politis yang baru.

Praktek pendisiplinan tubuh ini berjalan efektif di beberapa institusi tertutup yang memiliki aturan-aturan yang ketat seperti sekolah, rumah sakit, penjara, lembaga-lembaga pendidikan yang salah satunya ialah pesantren, pusat rehabilitasi, dan lainnya. Dalam konteks pondok pesantren fenomena disiplin tubh ini jelas terlihat, hal ini sebagaimana yang diketahui dalam kehidupan pesantren para santri diatur, diarahkan, dan dibentuk sedemekian rupa dengan aturan-aturan yang ketat sehingga menjadikan agar para santri disiplin dalam menjalankan rutinitas sehariharinya.

Pondok Pesantren Kebon Jambu Al-Islamy memiliki santri yang cukup banyak namun jumlah pengurusnya tergolong sedikit. Pondok Kebon Jambu mewajibkan para santri untuk bersama-sama melakukan aktivitas rutin, meliputi aktivitas rutin harian, mingguan, bulanan dan tahunan. Hal tersebut menjadi suatu kebiasaan para santri dan para santri menganggapnya sebagai suatu yang wajar karena adanya seperangkat aturan-aturan yang ketat yang diterapkan oleh Pondok Pesantren agar aktivitas tersebut bisa terlaksana dengan baik. Para santri dituntut untuk

${ }^{1}$ Sunu Hardiyanta, Michael Foucault Disiplin Tubuh Bengkel Individu Modern (Yogyakarta: LKIS,1997). hlm. 16

${ }^{2}$ Ibid. hlm. 74 
melaksanakan kegiatan-kegiatan tersebut dan mentaati peraturan yang diterapkan di Pondok Pesantren.

Dari pemaparan diatas, penulis melihat adanya kuasa terhadap tubuh santri yang ada di Pondok Pesantren Kebon Jambu sehingga melahirkan pelipatgandaan kekuasaan, dimana dengan jumlah pengurus yang sedikit mampu menaklukan ratusan atau bahkan ribuan santri untuk senantiasa patuh dan taat dalam melaksanakan kegiatan-kegiatan yang telah diatur oleh Pondok Pesantren. Dari pemaparan tersebut, secara umum penulis ingin mengetahui tentang proses-proses jalannya kekuasaan terhadap disiplinisasi tubuh yang ada pada kehidupan santri Pondok Pesantren Kebon Jambu secara lebih mikro, sehingga untuk dapat membedah masalah utama penelitian tersebut diperlukan beberapa metode yang terangkum dalam metodologi berikut.

\section{B. Metodologi}

Penelitian ini merupakan penelitian lapangan degan menggunakan pendekatan kualitatif. Penelitian ini difokuskan pada kegiatan dan aktifitas kehidupan santri yang ada pada Pondok Kebon Jambu Pesantren Babakan Desa Babakan Kecamatan Ciwaringin Kabupaten Cirebon. Adapun sumber data primer dari penelitian ini diambil dari para santri dan pengurus Pondok Kebon Jambu Al-Islamy serta para alumni yang masih berperan aktif dalam sistem kedisiplinan di Pondok Kebon Jambu AlIslamy dengan cara melakukan wawancara mendalam. Disaming itu untuk melengkapi data secara komprehensif dilakukan pula upaya observasi dan studi dokumentasi baik terkait dengan sumber-sumber materi tentang pemikiran Michel Foucault maupun tentang Pondok Pesantren Jambu AlIslamy. Hasil data yang diperoleh kemudian dianalisis dengan menggunakan kerangka teori displin tubuh dari Michel Foucault, sehingga akan didapatkan gambaran mengenai relasi kuasa atas pendisplinan tubuh yang ada dalam kehidupan santri di Pondok Kebon Jambu Al-Islamy tersebut.

\section{Michel Foucault: Sebuah Biografi Singkat.}

Michel Foucault dilahirkan di sebuah kota kecil di Prancis yang bernama Poiters pada tanggal 15 Oktober 1926. Nama kecilnya adalah Paul Foucault yang diambil dari nama ayahnya, kemudian ditambahkan oleh ibunya menjadi Paul Michel Foucault. Foucault terlahir sebagai anak 
kedua dari tiga bersaudara. Kakak perempuannya bernama Francine Foucault dan adik laki-lakinya bernama Deny Foucault.

Para ahli yang mendalami pemikiran Foucaut selalu merasa kesulitan untuk menggolongkannya kedalam disiplin ilmu dan aliran filsafat tertentu, hal tersebut dikarenakan Foucault memiliki banyak minat dan menguasai berbagai macam disiplin ilmu. ${ }^{3}$ Secara garis besar, Foucault adalah seorang sosiolog, filsuf, sejarahwan dan sekaligus psikolog. $^{4}$

Foucault terlahir dari keluarga ilmuwan, dimana ayahnya merupakan seorang profesor anatomi dan bekerja sebagai ahli ibadah yang sukses namun memiliki pemikiran yang kolot dan ibunya adalah putri seorang ahli bedah. Meskipun Foucaut pernah ditawari untuk memasuki pendidikan kedokteran, namun ia menolak dan lebih tertarik ke bidang filsafat, sejarah dan psikologi. ${ }^{5}$

Foucault ingin mengikuti jejak kakaknya Francine Foucault, sehingga pada tahun 1930 ia didaftarkan di kelas elementer di Lycee Henry-IV. Dua tahun setelah itu ia pindah ke Lycee Proper sampai tahun 1936 dan kemudian ia masuk ke Lycee Henry IV di Poiters sampai 1940. Selanjutnya ia meneruskan pendidikan setingkat SMA di College StaintStainlas sampai pada tahun 1943. Lalu ia melanjutkan ke sekolah bergengsi Lycee Henry IV di Paris dan memasuki kelas khusus karena ingin melanjutkan pendidikannya di ENS (Ecole Normale Sperieure). ENS merupakan salah satu sistem Grandes ecole (semacam sekolah tinggi) di Prancis. Foucault melanjutkan studinya di ENS pada tahun 1946 karena ia memiliki reputasi terbaik dalam filsafat. Selama sekolah di ENS, Focault mengambil studi filsafat dan Psikologi. Dari sini ia mulai mengenal tulisan filsuf-filsuf yang berpengaruh. Foucault dikenal sebagai pemikir yang cerdas dan di hormati. Ia menghabiskan waktunya untuk belajar selama bertahun-tahun di Swedia, Polandia, dan Jerman.

\section{Pondok Kebon Jambu Al-Islamy Pesantren Babakan Ciwaringin Cirebon}

\footnotetext{
${ }^{3}$ Ibid. hlm. 1

${ }^{4}$ Nanang Martono, Sosiologi Pendidikan Michel Foucault, (Jakarta: PT RajaGrafindo Persada, 2014) hlm. 11

${ }^{5}$ Sunu Hardiyanta, Michael Foucault Disiplin Tubuh Bengkel Individu Modern, hlm. 3
} 
Pondok Pesantren Kebon Jambu Al-Islamy merupakan salah satu pondok pesantren yang masih menganut tradisi salaf dari ribuan pondok pesantren yang ada di Indonesia. Pondok Pesantren ini terletak di desa Babakan Kecamatan Ciwaringin Kabupaten Cirebon pada tanggal 20 November 1993 dibawah naungan Yayasan Tunas Pertiwi. Pondok pesantren ini didirikan oleh seorang Kiai kharismatik yang bernama $\mathrm{KH}$. Muhammad atau yang biasa dipanggil oleh para santri dan masyarakat sekitar dengan sebutan "Akang”.

Desa Babakan Kecamatan Ciwaringin Kabupaten Cirebon sendiri memang identik dengan julukan kota santri, dimana Babakan sering disebut sebagai babak awal bagi orang yang ingin mempelajari ajaranajaran Islam. Pada abad ke 16 wilayah Babakan ini mulai dijadikan sebagai tempat perkembangan pendidikan Islam di wilayah Cirebon dengan tokoh pejuang pertamanya yaitu Syaikh Hasanudin atau yang dikenal dengan nama Kiai Jatira. ${ }^{6}$ Bermula dari Pondok Pesantren yang didirikan oleh Kiai Jatira yang terletak di sebelah utara kota babakan ini menarik para penuntut ilmu untuk mempelajari ilmu-ilmu agama disana. Seiring berjalannya waktu dan berkembangnya zaman, saat ini lembaga pendidikan Islam yang ada di desa Babakan semakin bertambah. Tercatat hingga saat ini terdapat kurang lebih 40 Pondok Pesantren dan juga lembaga-lembaga pendidikan Formal yang mengacu pada pendidikanpendidikan agama baik lembaga dibawah naungan DIKNAS maupun KEMENAG. $^{7}$

Sebelum mendirikan Pondok Pesantren Kebon Jambu Al-Islamy, KH. Muhammad mendapatkan amanat dari gurunya yaitu KH. Muhammad Sanusi Al-Babakani untuk mengasuh sebuah pondok pesantren yang bernama Kebon Melati pada tahun 1975. Karena semakin banyaknya santri yang berminat untuk belajar di Pondok Kebon Melati, akhirnya pada tanggal 20 November tahun 1993 KH. Muhammad mendirikan Pondok Pesantren Kebon Jambu Al-Islamy yang terletak lebih

${ }^{6}$ KH. Zamzami Amin, Baban Kana Pondok Pesantren Babakan Ciwaringin dalam Kancah Sejarah untuk Melacak Perang Nasional Kedongdong 1802-1919, hlm 77

${ }^{7}$ Wawancara dengan Ustadz Moh. Abdul Hakim, M.Pd.I, Senin, 06 Juni 2016, pukul 13.00 WIB, Tempat Kantor Pusat Pondok Pesantren Kebon Jambu Al-Islamy. 
keselatan dari pondok Kebon Melati untuk meningkatkan perkembangan dan kualitas pesantren yang setiap waktu semakin berkembang pesat. ${ }^{8}$

Layaknya pondok pesantren salaf lainnya, Pondok Kebon Jambu masih mengajarkan kitab-kitab klasik atau yang biasa disebut dengan kitab kuning dengan metode-metode pengajaran pesantren salaf pula, seperti bandungan (metode ceramah) dan sorogan (face to face). Pondok Kebon Jambu juga menerapkan sistem klasikal pendidikan berupa jenjang pendidikan bagi santri dari mulai tingkat persiapan/pra tingkatan lalu naik ke tingkat 1 (fasholatan) hingga tingkat 6 (fathul mu'in). Kenaikan tingkatan ini dilakukan setiap tahunnya dengan seleksi dan ujian-ujian yang sangat ketat. Selain kedua metode tersebut, Pondok Kebon Jambu juga menggunakan metode Madrasah yang dinamakan dengan Madrasah Tahsinul Akhlaq Assalafiyah (MTAS). Sistem madrasah ini sudah dipakai sejak tahun 1987 ketika KH. Muhammad masih mengasuh di Pondok Kebon Melati.

Dalam melakukan aktivitasnya para santri Pondok Kebon Jambu memiliki aktivitas yang cukup padat. Dari pagi hari dimana para santri wajib bangun pada pukul 04.00 WIB dan langsung melakukan Qobliyahan (nderes kitab-kitab nadzoman seperti Tashrifan, Imrithi, Alfiyah, dan Jauharu Al-Maknun) dan melakukan pengajian bandungan dan sorogan setiap $b a^{\prime} d a$ sholat fardhu hingga malam hari dimana seluruh santri wajib tidur pada pukul 23.00 WIB. Semua aktivitas tersebut sudah tersusun oleh peraturan-peraturan yang ada di Pondok Kebon Jambu Al-Islamy agar para santri melakukan kegiatan bersama-sama baik santri tingkat atas maupun tingkat bawah dan dapat menjadi individu yang disiplin.

Pada tanggal 1 November 2006 yang bertepatan dengan tanggal 9 Syawal $1427 \mathrm{H}$, keluarga besar Pondok Pesantren Kebon Jambu mengalami duka yang sangat mendalam, karena sang pendiri pondok pesantren yaitu KH. Muhammad wafat di rumah sakit pertamina Cirebon. Untuk melanjutkan kepemimpinan pondok pesantren Kebon Jambu sebagai pengganti KH. Muhammad, dibentuklah dewan pengasuh yang diketuai oleh istrinya yaitu Nyai $\mathrm{Hj}$. Masriyah Amva dan beranggotakan KH. Asror Muhammad (Putra Ke 2), K. Syafi'i Atsmari (Menantu), K. Syamsul Ma'arif (Menantu), K. Shodikin Ali, dan Ustadz Muhyidin

${ }^{8}$ Hj. Masriyah Amva. Akang di Mataku. (Cirebon: Salima Network dan Pondok Pesantren Kebon Jambu, 2013). hlm 239 
(Santri senior). Selain dewan pengasuh, dibentuk pula dewan pembimbing pesantren yang beranggotakan para alumni yang tinggal disekitar pesantren dan para santri senior yang telah menikah. Dewan pembimbing ini bertugas memberikan bimbingan dan arahan secara moril untuk pengembangan pendidikan Islam pesantren. Begitu hebatnya sosok kharismatik $\mathrm{KH}$. Muhammad sehingga untuk menggantikan satu orang KH. Muhammad perlu digantikan dengan beberapa Kiai dan Asatidz untuk melanjutkan kepemimpinan pondok pesantren Kebon Jambu Al-Islamy.

\section{E. Analisis Disiplin Tubuh dalam Kehidupan Santri Pondok Kebon Jambu}

Dalam karya-karyanya, Foucault menunjukan bahwa tubuh juga merupakan salah satu wilayah dimana relasi kuasa berjalan diatasnya. Relasi-relasi kuasa tersebut melatih, memaksa, menandai, membentuk, menanamkan dan menguasai tubuh. ${ }^{9}$ Foucault menyebutnya sebagai disciplinary power. Tubuh menjadi suatu kekuatan yang patuh dan berguna serta menjadi tubuh yang produktif. Penaklukan terhadap tubuh tersebut menjadi suatu pengetahuan terhadap tubuh. Penaklukan dan pengetahuan inilah yang menegakan tekhnologi politis terhadap tubuh.

Praktek-praktek disciplinary power ini bisa ditemukan di beberapa institusi dengan seperangkat aturan-aturannya seperti rumah sakit, penjara, lembaga pendidikan, pondok pesantren, akademi kemiliteran dan lain sebagainya. Misal dalam ruang lingkup Pondok Pesantren, dimana para santri dibentuk sedemikian rupa dengan aturan-aturan yang dibuat dan mengusahakan agar bagaimana mereka menjadi individu yang disiplin dalam rutinitas sehar-hari. Pondok pesantren biasanya mewajibkan para santrinya untuk melakukan aktivitas rutin secara bersama-sama, seperti: Sholat wajib berjama'ah, Sholat sunah berjama'ah, mengaji, sekolah, dan kegiatan lainnya.

Menurut Foucault, ada tiga upaya untuk membentuk prilaku tubuh yang taat dan dapat 'dikendalikan' dengan mekanisme pendisiplinan terhadap masyarakat modern. Pertama, melalui 'pengamatan atau pengawasan bertingkat (hierarkis)'. Dalam hal ini Foucault mencontohkannya dengan model 'panoptikon' dimana seorang pengawas dapat mengamati gerak gerik orang lain melalui menara pengawas tanpa diketahui oleh orang yang sedang diamati tersebut. Kedua, melalui

\footnotetext{
${ }^{9}$ Sunu Hardiyata. Michael Foucault Disiplin Tubuh Bengkel Individu Modern, hlm 28
} 
normalisasi. Mekanisme pendisiplinan melalui normalisasi ini sebenarnya sudah ada dan digunakan oleh masyarakat tradisional namun masih digunakan oleh masyakarakat modern. Normalisasi ini merupakan instrumen kekuasaan pendisiplinan yang menjadi instrumen penilaian untuk mengukur, mengelompokan, dan mengategorikan individu sesuai standar atau norma tertentu. Ketiga, adalah pengujian yang berdasarkan dari penggabungan penilaian model pengamatan hierarkis dan normalisasi. ${ }^{10}$ Adapun konsep disciplinary power yang terdapat di Pondok Kebon Jambu Al-Islamy Pesantren Babakan Ciwaringin Cirebon adalah sebagai berikut :

\section{Pengawasan Hierarkis}

Secara genealogi, pengawasan hierarkis di Pondok Kebon Jambu, terbagi menjadi dua yaitu konsep ruang dan kontrol aktivitas.

\section{a. Konsep Ruang}

Konsep ruang mendukung sistem dan aturan-aturan yang ketat dalam setiap terjadinya praktek kuasa tubuh yang membentuk individuindividu yang patuh. Konsep ruang ini terinspirasi dari model Panoptisisme, yaitu suatu model penerapan disiplin yang keras dan ketat menurut model arsitektual yang dirancang oleh seorang filsuf dari inggris pada abad ke 17 yang bernama Jeremy Bentham. Panoptikon yang dikenalkan oleh Jeremy Bentham merupakan sebuah konsep ruang penjara yang berbentuk melingkar dan terdapat sebuah menara tinggi ditengahnya yang berfungsi sebagai pemantau semua aktivitas narapidana setiap saat. Melalui mekanisme ini, pengawas dapat terus menerus mengawasi tanpa diketahui oleh narapidana tersebut. Begitupun sebaliknya, narapidana penghuni sel panoptikon senantiasa diawasi tanpa mengetahui siapa yang mengawasinya.

Mekanisme pemantauan semua aktifitas santri Pondok Kebon Jambu juga memiliki fungsi yang sama dengan panoptikon Jeremy Bentham. Setiap waktunya para santri selalu diawasi seluruh pengurus yang tersebar di seluruh wilayah Pondok Kebon Jambu. Para pengurus di Pondok Kebon Jambu Al-Islamy terdiri dari pengurus kamar, pengurus komplek, dan pengurus pusat. Pengurus kamar bertugas memantau seluruh kegiatan para santri yang ada di kamar, sedangkan pengurus komplek

\footnotetext{
${ }^{10}$ Nanang Martono. Sosiologi Pendidikan Michel Foucault, hlm 87-92
} 
memantau semua gerak gerik santri yang ada di komplek dan kamar, sedangkan pengurus pusat memantau semua aktivitas santri secara menyeluruh yang ada di Pondok Kebon Jambu melalui laporan-laporan dari pengurus komplek dan kamar. Melalui mekanisme ini, para pengurus dapat terus menerus memantau tanpa diketahui oleh para santri siapa yang sedang memantaunya. Sedangkan para santri senantiasa merasa diawasi tanpa mengetahui siapa yang sedang mengawasinya.

Dalam sistem panoptikon ini, kuasa berfungsi secara otomatis. Individu-individu yang ada dalam sel menjadi sadar bahwa dirinya terus menerus diawasi. Dilain pihak, hal terebut tidak berefek kepada siapa-siapa yang menjalankan kuasa karena mereka tidak bisa mengetahui siapa yang sedang mengawasinya. Panoptikon ini menjadi tekhnologi yang mengotomatiskan kuasa tanpa perlu melalui pribadi yang berkuasa seperti halnya raja, melainkan dengan penyebaran individu, pemantauan dan melalui aturan-aturan yang memiliki mekanisme dan dapat menciptakan relasi-relasi yang menguasai tubuh, sehingga panoptikon ini memberi gambaran positif tentang praktik kuasa dan disiplin.

Disiplin yang semula dimaksudkan untuk menetralisir bahaya, menghindari penyelewengan, dan mengoreksi segala kesalahan, saat ini disiplin diminta untuk memiliki peran positif. Disiplin yang ada di Pondok Kebon Jambu misalnya, bukan hanya untuk mencegah pelanggaran dan terciptanya pengajian yang kondusif, melainkan menjadi cara untuk membentuk para santri menjadi individu trampil, cekatan, sehingga kesatuan yang dibangun berdasarkan kemampuan individu-individu yang patuh dan berguna tetap terjaga.

Fungsi disiplin di Pondok Kebon Jambu dilaksanakan oleh para pengurus. Meskipun para pengurus ini dipandang sebagai ekspresi langsung dari kuasa absolut kyai, karena kyai memberikan wewenang kepada mereka untuk meneruskan kuasanya, namun bentuk kuasa yang dilaksanakan, mekanisme yang dijalankan dan elemen yang diterapkan bersifat khusus. Para pengurus dalam melaksanakan fungsinya harus memperhatikan segala sesuatu, termasuk segala hal yang dianggap kurang penting. Untuk melaksanakan pengawasan tersebut, maka kuasa harus menyediakan perangkat tetap yang mampu mengadakan pemantauan tanpa pernah dilihat, yakni agen-agen rahasia yang bertugas memantau dan mencatat tingkah laku individu. 


\section{b. Kontrol Aktivitas dan Perilaku}

Disamping pengawasan konsep ruang, disciplinary power dalam Pondok Kebon Jambu juga diperketat dengan kontrol aktivitas dan prilaku para santri. Usaha ini dilakukan terutama untuk menciptakan individuindividu yang patuh. Kontrol aktivitas ini misalnya terlihat dari penerapan sistem aktivitas yang ada di Pondok Kebon Jambu yang senantiasa dilakukan secara bersama-sama dalam waktu yang sama dan berada di dalam lokasi yang sama berdasarkan jadwal yang dibuat oleh Pondok Kebon Jambu. Disamping itu bentuk-bentuk kegiatan santri ini juga diatur oleh Pondok, dikelompokan sesuai dengan tingkatannya masing-masing. Kegiatan yang bersama-sama inilah nantinya akan membentuk individuindividu yang patuh. Sebagaimana yang dikatakan Foucault, disiplin dapat menyentuh tubuh dari berbagai kontrol aktivitas yang dicapai dengan cara pengaturan waktu, pembentukan ketepatan antara waktu dengan tindakan, penciptaan sikap tubuh yang efisien, penciptaan relasi yang efisien antara tubuh dan alat-alat, dan pengefektifan waktu yang meningkat terusmenerus. ${ }^{11}$

Setelah itu, tubuh dilatih untuk membentuk ketepatan antara waktu dengan suatu tindakan. Hal ini dapat dilihat dalam setiap kegiatan yang ada di Pondok Kebon Jambu. Seluruh gerak santri diatur oleh hitungan waktu yang teratur. Ada kalanya waktu untuk beristirahat dan santai, adapula waktu untuk melangkah lebih cepat dalam setiap melaksanakan segala kegiatan secara teratur. Seluruh gerak dilakukan dengan menempati hitungan waktu secara persis. Dari sini terlihat jika waktu sudah menembus tubuh dan kuasa waktu mengontrol aktivitas tubuh dengan teliti. Melalui disiplin ini, menghasilkan ketepatan sikap tubuh dalam melakukan suatu tindakan tertentu. Para santri dituntut untuk memanfaatkan waktunya dengan baik, semisal ketika santri ingin berpergian namun jika waktunya mepet dengan kegiatan pesantren maka santri pun mengurungkan niatnya untuk berpergian. Tubuh santri dilatih untuk menemukan sikap yang tepat bagi suatu aksi atau tindakan sehingga penggunaan waktu bisa lebih efektif dan efisien.

Dengan adanya kontrol aktivitas tersebut sehingga disiplin dapat menawarkan prinsip penggunaan waktu yang efektif untuk terus meningkat dan menghapus bahaya pemborosan waktu. Dari disiplin ini, santri akan

\footnotetext{
${ }^{11}$ Ibid. hlm 83
} 
menemukan penggunaan waktu secara terus menerus menuju suatu titik keefektifan yang maksimum, yakni dalam ketepatan yang teratur. Tubuh ditaklukan dengan rezim keteraturan dan ketepatan waktu. Melalui penembusan kuasa waktu terhadap tubuh, maka terjadilah penaklukan terhadap tubuh. Melalui cara ini dibentuk suatu objek baru dari kuasa, yakni tubuh yang terlatih dan berguna.

\section{Normalisasi}

Sebagaimana yang telah disinggung sebelumnya bahwa normalisasi merupakan instrumen kekuasaan pendisiplinan yang menjadi instrumen penilaian untuk mengukur, mengelompokan, dan mengategorikan individu sesuai standar atau norma tertentu. Dalam inti disiplin, Foucault memperhatikan adanya mekanisme hukuman kecil mengenai ketidaktepatan waktu, aktivitas, tingkah laku, wicara, tubuh, dan seksualitas sebagai sesuatu yang dapat menyadarkan individu menyadari telah melakukan suatu pelanggaran.

Penerapan instrumen normalisasi tersebut dalam konteks Pondok Kebon Jambu dapat dilihat dari beberapa hukuman yang diterapkan oleh Pondok pesantren tersebut. Misalnya dalam kasus ketidaktepatan waktu, Pondok Kebon Jambu memberikan hukuman kepada santri-santrinya jika ia terlambat atau tidak hadir dalam setiap kegiatan di Pondok. Dari segi aktivitas, Pondok menghukum para santri yang tidak semangat dalam melakukan aktivitasnya semisal hapalan yang kurang dari target karena tidak semangat menghafal. Dari segi tingkah laku, Pondok akan menghukum santri yang tidak sopan dan tidak taat terhadap aturan-aturan yang ada di pesantren maupun diluar pesantren. Segi wicara, Pondok menghukum santrinya yang berbicara kasar atau berbohong. Dan dari segi seksualitas, pondok juga menghukum santri yang selalu menuruti hawa nafsunya dan tidak melaksanakan 'sesuatu' sesuai tempatnya (tidak murni). Hukuman-hukuman tersebut dimaksudkan agar para santri sadar bahwa ia telah melakukan suatu pelanggaran yang tak boleh terjadi lagi.

Sebagaimana yang konsepsikan oleh Foucalt, hukuman disiplin ini juga tidak hanya mengacu pada ketaatan terhadap keteraturan yang telah ditetapkan oleh hukum, program dan peraturan, melainkan juga pada kodrat alami. ${ }^{12}$ Kodrat alami dijadikan ukuran pelaksanaan hukuman.

${ }^{12}$ Sunu Hardiyanta. Michael Foucault Disiplin Tubuh Bengkel Individu Modern, hlm 95 
Misalnya dalam konteks Pondok Pesantren Jambu, santri akan diberikan hukuman sesuai dengan apa yang ia lakukan, santri yang tidak mencapai target setoran karena males menghapal akan mendapatkan hukuman yang lebih berat ketimbang santri yang tidak mencapai target setoran karena ketidakmampuan otaknya. Jadi dalam rezim disiplin, hukuman bersifat fleksibel yang mengacu baik pada hal-hal yuridis maupun alami.

Sistem disiplin ini juga lebih menyukai hukuman yang bersifat melatih. Di Pondok Kebon Jambu, hukuman disiplin berfungsi menentukan tingkat dan pemisahan. Para santri yang didapati tidak mampu, tidak akan naik ke tingkat selanjutnya. Setelah itu akan dilatih dan diuji kembali sampai santri tersebut dianggap mampu untuk meneruskan ke tingkat selanjutnya. Jadi menghukum tak hanya mengkoreksi suatu kesalahan, tetapi juga melatih santri agar dapat menjadi individu yang berguna.

Selain menghukum, hukuman disiplin juga memiliki fungsi mengganjar. Menghukum dan mengganjar ini berfungsi dalam proses pelatihan dan koreksi. Para pengurus ditekankan untuk lebih memberikan ganjaran ketimbang memberikan hukuman. Para santri akan lebih terdorong ketika diberi hadiah bagi santri yang berhasil menghapalkan kitabnya dari pada rasa takut yang ditimbulkan dari hukuman jika santri tersebut kurang hafalan. Disiplin menentukan individu-individu secara benar, individu akan diketahui secara tepat. Dengan begitu hukuman mengintegrasi pengetahuan terhadap individu. Dengan demikian, normalisasi menjadi perangkat kuasa yang bukan hanya menghasilkan 'keserupaan' tetapi juga 'mengindividualisasikan' individu dengan menciptakan jarak yang membatasi, menentukan tingkat, menentukan spesialisasi dan mengubah perbedaan menjadi berguna dengan membuat cocok yang satu terhadap yang lain. ${ }^{13}$

\section{Examination}

Salah satu instrumen yang cukup jelas dalam penerapan examination ialah ujian. 'Ujian' merupakan pemantauan normalitatif yang mampu mengklasifikasi, menentukan mutu, dan menghukum subjek yang dipantau. Dari ujian ini menjadikan individu lebih 'terlihat' dan orang akan bisa menilai dan menentukan individu tersebut. Agar individu bitu

${ }^{13}$ Sunu Hardiyanta. Michael Foucault Disiplin Tubuh Bengkel Individu Modern, hlm 98 
bisa 'terlihat' maka ujian ini diritualkan. Dalam menyelidiki 'ujian' secara arkeologi, Foucault menemukan seluruh wilayah pengetahuan dan seluruh model kuasa. Foucault menyelidiki secara khusus bagaimana upacara ujian dilaksanakan, seperti apa metodenya, bagaimana karakter, peran, permasalahan, jawaban, sistem tanda dan klasifikasi dari ujian tersebut.

Secara arkeologi, di Pondok Kebon Jambu juga memiliki mekanisme ujian yang teratur. Mekanisme ini terlihat misalnya pada penerapan pengajaran dan pengawasan yang dilaksanakan rutin oleh para ustadz atau para pengajarnya. Ustadz di Pondok Kebon Jambu selaku pengajar memiliki waktu yang teratur untuk mengajarkan ilmunya kepada para santri. Setiap pengajian dari jadwal yang sudah diatur oleh Pondok, Ustadz senantiasa memeriksa sejauh mana kemampuan para santri dari ilmu yang sudah diajarkan. Jika para santri dianggap menguasai ilmu yang telah diajarkan, maka ustadz melanjutkan materinya, dan Ustadz akan mengulangi materinya jika para santri dianggap belum menguasai pelajarannya.

'Ujian' terhadap para santri menjadikan ustadz menjalankan peran yang ditentukan oleh pondok pesantren sekaligus ditaklukan dalam teknik 'ujian', karena semakin sering Ustadz melakukan 'ujian' terhadap santri maka semakin cepat materi yang ia capai sesuai dengan target yang telah ditentukan oleh pondok pesantren. Pondok pesantren kemudian menjadi tempat latihan dan tempat korelasi pengetahuan serta membalik relasi kuasa dan penegakan tubuh pengetahuan.

Pengamatan dan ritual kekuasaan maupun penyebaran kekuatan dan pendirian kebenaran semuanya tergabung dalam proses ujian ini. Jika dipandang secara genealogi, inti prosedur disiplin ini adalah mewujudkan suatu penaklukan terhadap individu. Individu ditaklukan dalam suatu mekanisme pemantauan dan melalui mekanisme ini objek ditaklukan dan ditentukan statusnya secara objektif dari mulai kemampuannya, kelasnya, kualitasnya, dan tempatnya.

Disamping ujian dalam arti pemantauan hasil belajar secara rutin, mekanisme ujian juga dilaksakan secara formal. Setiap akhir semester di Pondok Kebon Jambu selalu mengadakan ujian akhir semester sebagai bentuk representasi pengawasan kedisiplinan di sekolah dan sekaligus merepresentasikan mekanisme pengawasan secara langsung kepada siswa. Ujian akhir semester merupakan sebuah mekanisme evaluasi dan 
perbandingan secara serentak yang terjalin dalam Pondok Pesantren melalui ritual kekuasaan yang terulang secara terus menerus.

Selain ujian akhir semester, setiap akhir tahun Pondok Kebon Jambu juga mengadakan Musabaqoh atau perlombaan yang melibatkan seluruh santri Pondok Kebon Jambu. Musabaqoh ini memiliki berbagai cabang dari mulai membaca kitab (Qira'atul Kutub), Membaca Al-Quran (Tilawatul Quran), puisi, pidato, sholawat, resensi kitab, kaligrafi dan lain sebagainya. Musabaqoh dimulai dari penyeleksian ke kamar-kamar. Setelah itu, para pemenang mewakili kamarnya masing-masing untuk bertanding di Kompleknya masing-masing. Para juara komplek pun nantinya akan dilombakan kembali di musabaqoh bergengsi antar komplek. Hasil musabaqoh ini digunakan untuk mengelompokan santrisantri ke dalam kategori-kategori tertentu sesuai standard penilaian para juri. Kecakapan dalam setiap cabang lomba yang mereka ikuti dikembangkan sebagai bentuk disiplin dan diferensiasi. ${ }^{14}$

\section{F. Kesimpulan}

Praktek pendisiplinan tubuh yang ada di Pondok Kebon Jambu Pesantren Babakan Ciwaringin Cirebon terbentuk melalui beberapa konsep yang saling terbagi dan saling menguatkan, diantaranya adalah: Pengawasan secara hierarkis, Normalisasi, dan terakhir adalah ujian.

Pengawasan Hierarkis di Pondok Kebon Jambu merupakan sebuah konsep pengawasan secara bertingkat dari mulai bagian terkecil yaitu kepala kamar, hingga pengawasan dari pengurus pusat dan dewan pengasuh. Pengawasan hierarkis akan berlangsung secara terus menerus dan lebih fungsional untuk memperluas mekanisme kuasa. Sehingga disiplin menjadi kuasa yang tak disadari serta berfungsi secara otomatis dan melipatgandakan kuasa.

Normalisasi di Pondok Kebon Jambu merupakan instrumen kekuasaan pendisiplinan yang menjadi instrumen penilaian untuk mengukur, mengelompokan, dan mengategorikan individu santri sesuai standar atau norma yang berlaku di Pondok Kebon Jambu. Adapun konsep ujian yaitu diambil dari penggabungan penilaian model pengamatan hierarkis dan normalisasi.

\footnotetext{
${ }^{14}$ Nanang Martono. Sosiologi Pendidikan Michel Foucault, hlm 112
} 
Dari adanya kajian ini dapat dikataan bahwa kita semua adalah bagian dari mekanisme kuasa itu sendiri, sehingga melalui kesadaran tersebut diharapkan lahirnya kesanggupan untuk menggunakan kuasa secara baik yang bermanfaat bagi kepentingan orang banyak. Karena banyak yang tak menyadari bahwa dirinya berperan dalam kuasa, sehingga mereka belum menerima dan menghargai peran mereka dalam suatu relasi kuasa baik atau tidak. Ketidaksadaran mereka pun menimbulkan berbagai tindakan dan sistem yang represif dan menyeragamkan.

\section{Daftar Pustaka}

Amin, Zamzami. 2014. Baban Kana Pondok Pesantren Babakan Ciwaringin Dalam Kancah Sejarah Untuk Melacak Perang Nasional Kedongdong 1802-1919. Bandung: Pustaka Aura Semesta

Amva , Masriyah. 2013. Akang di Mataku. Cirebon: Salima Network dan Pondok Pesantren Kebon Jambu.

Hardiyanta, Sunu. 1997. Michael Foucault Disiplin Tubuh Bengkel Individu Modern. Yogyakarta: LKIS,

Martono, Nanang. 2014. Sosiologi Pendidikan Michel Foucault. Jakarta: PT Raja Grafindo Persada. 